\title{
Determinants of Privatization: Evidence from Pakistan
}

\author{
MUHAMMAD TAHIR KHAN \\ Lecturer, Abdul Wali Khan University Mardan \\ mtahir@awkum.edu.pk \\ DR.ADNAN AHMAD \\ Assistant professor, Abdul Wali Khan University, Mardan \\ adnankhattak@awkum.edu.pk \\ DR. JEHANGIR \\ Assistant professor, Abdul Wali Khan University, Mardan \\ janikhan@awkum.edu.pk \\ SAQIB SHAHZAD \\ Demonstrator, Abdul Wali Khan University, Mardan \\ PhD Scholar, Institute of Management Sciences, Peshawar \\ saqibshahzad26@gmail.com
}

\begin{abstract}
Privatization is something that can take the ownership factor from state and give it to other and since form 1990's it has turned out to be a most important for both the developing countries as well as for the developed countries. However, in this study we identify the determinants that can lead the government of Pakistan towards privatization by relying on the data that has been taken from privatization commission of Pakistan (PCP) and state bank of Pakistan database between the years 1991 to 2014. Our results identify that the decision for privatization has been initiated by external factor i.e international financing agencies and after that it has been shaped by internal factors that is basically due to economic condition.
\end{abstract}

\section{Keywords: Determinants, Privatization}

\section{Introduction}

The recent trend of privatization shows that state owned enterprises (SOEs) are not performing well and that may trigger the privatization process. Privatization is basically defined as, the transfer of control and ownership of SOE to private investors, that is started by THATCHER Government and then it is spread across countries. In Pakistan, the privatization process began in 1991 through the foundation of privatization commission of Pakistan (PCP). The main reason behind the establishment of PCP was to dispose of huge losses by SOEs and to decrease the loan burden. "The PC Ordinance determines that 90 percent of privatization revenue will be utilized for debt obligation and 10 percent for poverty. And by reducing the external debt it can help in strengthen the 
fiscal policy" (privatization commission of Pakistan). There are still different arguments are going on that to re-nationalize the state-claimed assets. Driven by external factors while the degree and scope of privatization is shaped by internal factors i-e political and economic condition of that country (Breen \& Doyle, 2013). As because of some un ethical, worst macro-economic and questionable financial strategies of the last quarter century and due to which unacceptable performance of state owned enterprises (SOEs) that can trigger the privatization process and then it is turned out to be the most important part that can generate revenue, reduce debt level and considered helpful in developing countries.

Sheshinski and Calva (2003) disclose that after two decades of the independence of Pakistan the nationalization process was begun that was a huge tragedy for the economy of Pakistan that have ended the excellent era of industrialization for long. It is said because the biased decision of huge investments was made through the taxes of public money foreign debt as the money of public and that was exposed to huge corruption and losses in the state owned enterprise. Although the SOEs that time has gone to the good performance stage due to large investments in the shape of equity and debts but unfortunately the U-turn was taken by that time governments to privatize them again. This approach was almost very swift and unreasonable that is always subjected to corruption charges. It is said that it was done to take over the inefficiencies and corruption in these units due to which these units were considered as huge burden on budget because of almost incurring huge losses. On the other hand it was done for reducing the foreign debt through the sale of these enterprises. The adverse impact of privatization process and the manner it was carried lead the nations to billions of losses through tax evasion and under payment of government bills. On the average the net transfer to SOE'S $\mathrm{s}$ is reduce by privatization. The tax collection from privatized firms become favorable transfer to the SOEs.

As mentioned above the financing of these state owned enterprises was done through high cost foreign debt, equity and borrowings from local financing institutions and by agreeing on unfavorable loan conditions from donor agencies such as ADB (Asian development bank), world bank, IMF and including the aids from soviet union. The devaluation of intrinsic value of rupee and inflation in the country, with the passage of time made the situation more worst and the cost of capital in these investments spontaneously increased. Therefore, considering the cost that is incurred on these investments the reserve price was mentioned and specified for them till privatization. During the 1990's, the proceeds from privatization sales that received around the world topped $\$ 1$ trillion and further increase 180 billion in 2000 . Thus privatization reduce the fiscal burden of many states and change the world economic scene. While governments continue to implement privatization around the world that show increase in sales, profitability, operating efficiency and also there is decrease in the debt level (Megginson, 2000).

A survey is being conducted in 17 American countries and found out that over sixty percent of the respondent is disagree with the privatization and thought that it is not beneficial but the remaining forty percent are not agree with that and says that state 
should not involve themselves in the business and leave it to private sector (Lora \& Panizza,. 2003; Cefir, 2007). But, in the early 1990's to mid, most of the countries privatize their state owned enterprises (SOEs), initially it was going towards decline but at the end of 1990's and onward, the economies is growing at the average GDP of 5.5 percent in 28 post-communist countries (Denisoval et al. 2007). So, we can say that in countries where growth rate is higher then there will be lower demand for renationalization and more demand for privatization. As we look at the component there are different opinions about privatization, some people wants to go with privatization, some with nationalization and some countries privatized more widely than others. So each nation have different reasons and it is normally recognized that privatization has strong political support and also right wing governments are more interested towards privatization (Yarrow \& Perotti, 2000).

The process of privatization was being criticized by during all the governments for different causes. Many units that were very productive and were earning a good sum of profit were sold out for throughout prices instead of their real value of asset. The act of privatization leads to corruption and the estimated amount that is exploited in privatization was reported by anti-privatization alliance was 1550 billon Pakistanis rupee and $\$ 23.83$ billion int he regime of Musharraf while pushing the privatization process and the amount received from this nationalized asset sold out to privatize investors were used for current expenditures due to which there was no fiscal impact and the money was not utilized for productive purpose (khan). Privatization of steel mill was stopped by supreme court due to this reason. According to different survey's it was never happened that government completely transfer the control and ownership to private investors. A survey in 41 countries b/w 1977-1997 by (Bartolotti et al, .2000) shows that only $41 \%$ of the stocks are sold to private investors that show control is still in the state hands. So why do they privatize? Therefore, this study required in-depth research to uncover the determinants that can lead to privatization. It will also help the regulators in stabilizing the economy and policy making.

\subsection{Significance of the Study}

This study will help the regulators in stabilizing the economy and policy making and also it will help out researchers to know about the determinants that lead towards privatization and this research will help government that under which circumstances the state should adopt privatization.

\subsection{Objective of the Study}

To investigate the determinants that leads towards privatization?

\section{Literature Review}

As there are large number of literature's available on privatization that measures pre-post performance of privatization and its determinants related to specific country or specific area, but no study is available in the literature that investigate the reasons and performance of privatize firms in Pakistan. Megginson, Nash and Vanrandenborgh (1994) reveals in their study that privatization increase overall profit by increasing their sales, investment decision and their operating efficiency and also reduce debt level and increase dividend payments and also find out that there is no decrease in employment but rather 
they employ more people after privatization. Privatization depends on the reason that it will enhance firm performance and help nations to develop, the impact has been very difficult to recognize. In one of the research paper, the researcher identify that the fastest growing economies i-e china, Slovenia and Poland, have been among the slowest process of privatization, while the economies or countries that privatize more quickly or the process of their privatization is fastest, for example Ukraine, Russia, and the Czech Republic, after they privatize their firms in the 1990s face decline or slow growth. privatization not only itself develop the economy but rather they propose that a beneficial outcome will be produced when privatization is joined by inside and out institutional changes (Kocenda \& Svejnar, 2002).

The thing that put pressure on government to adopt privatization is trade liberalization, as the logic behind this is straight forward that government has to control market components, changing cost and wages, for this state have to raise taxes or to increase borrowing that directly effect the interest rate to raise (Garett, 1998). Therefore these factors force government to privatize and increase their efficiency and nowadays the global trend of privatization convince many states to adopt privatization and to increase their capital and to attract the investment opportunities often it reduce the prices and allow them to capture and to compete with the market. Secondly, the decision to privatize the state owned enterprises (SOEs) is shaped by the procedures of global trend and diffusion ( Brune, Garret \& Meseguer, 2004). Many states adopt privatization as a result of limited learning, they learns from global environment by the crisis in latin America, after the collapse of Soviet Union (Weylan, 2005; Meseguer, 2004).

Many researchers identify the important factor that initiate privatization in a country through pressurizing by international financing agencies (Bortolotti \& Pinotti, 2003; Mulherin, Netter \& Stegemoller, 2004) same is the case of Pakistan, the decision that is being taken by these international financing agencies is questionable, as they take the decision of privatization in countries without looking at that whether it would be successful in this type of environment or not. for example state bank of Pakistan is responsible for banks rules and regulation, security and exchange commission of Pakistan is responsible for non-banking firms in Pakistan. Similarly, Pakistan telecommunication authority (PTA), oil and gas regulatory authority (OGRA) are develop and working since before the process of privatization was started in pakistan, so how come these international regulatory authorities implement privatization without knowing anything about the ground realities. Many states is being pressurized or influence to adopt privatization by international financial institution (Guillen, Henisz \& Zellner, 2005). IMF was the first organization that lunch structural adjustment program (SAPs) in dept crisis of 1980 's, that include to adopt privatization, liberalize and to remove some economic activities in borrowing countries. After this first implementation of privatization program and structural changes, it become the common feature and essential part for the world bank and IMF program and specially for those countries who can't repay or generate the loan amount to repay. The basic reason behind the privatization program that it increases the efficiency and help them to recover their loan amount from the borrower's country (Biersteker, 1990). IMF pressurize the country that taken loan from them to privatize the 
state owned enterprises (SOEs) that perform inefficient and between 1977 to 1999 majority of privatization occur in 71 countries (Henisz, Zellner \& Gullner, 2005).Bartolotti, Siniscalco and Fantini (2003) reveals in his research that the most important factor that can pressurize the government to adopt privatization is that fiscal distress and by adopting such process it helps the state to finance their expenditure and to pay their creditors. By paying the creditors will reduce the amount of external debt and can give strong signal in the market and then the government can easily generate the payment at lower interest rate (Brown \& Biglaiser, 2003). Private firms are more effective and efficient then state owned enterprises (SOEs) in competitive environment, so it is more important factor then gaining ownership or control while evaluating performance Vickers \& Yarrow (1991). As we have seen the major shift of business industries to Bangladesh from Pakistan in present. As a Pakistanis analyst and researcher, Pakistan must have effective business environment like Bangladesh where the objective of the business organization can achieve their goal via better role of management. The objective must be the alliance of profitability of both the public and private firms and this cannot be achieve only by changing the ownership from public to private. It can contribute to economic growth, if the partaker playing the role in accomplishing the goal should not be corrupt and not seeking the commission and rent. They should be committed towards their motive of profit and effective activities. The development and improvement of the firm cannot be achieved through privatization only, either the policies should be made as affective along with privatization for promotion of economic growth (Akram, 1999).

Bortolotti and other researchers prove that right wing governments are more prefer privatization (Bortolotti et al., 2003) and furthermore, began privatization process sooner than left-wing governments. Bortolotti and Pinotti (2008) and Zellner, Henisz and Guillen (2005), reveals that international financial institution have influence on government to adopt privatization and also international monetary fund (IMF) in 1980 lunch first adjustment program in borrowing country. The essential explanation behind privatizing these firms is that the government should not be in the matter of running organizations but rather managing organizations. The role of government should be that of a neutral, who sets rules and regulations for organizations to work and maintained to punish those who break the rules. And if the government itself is one of the players in the business sector, there will be strong conflict and the other business sectors lose trust from the government. Akhtar (2010) reveals in his research by comparing both public and private firms that produced similar goods, find out that by changing ownership of firm from public to private is not an important condition for more productive operations or to increase revenue, however because of overstaffing and political interference it reduce the performance of state owned enterprise (SOE). In this respect due to restructuring in Pakistan many firms closed after privatization. In developed nations the approach of political economy is very helpful in understanding that why and how governments privatize. They further argued that due to political influences it shape the privatization process and right wing governments spread ownership among domestic investors (Bartolotti \& Pinotti, 2003; Galal, Jones, Tendon \& Vogelsang, 1994). Megginson, Nash 
and Randenborgh (1994) explore in their study and found out that there is no such case in which anyone can lose due to privatization. Sadder (1993) reports that in between 1998 to 1992 , the privatization process in developing countries raised revenue from $\$ 2.6$ billion to $\$ 23.2$ billion. However it's a good achievement through privatization but only this objective will narrow down the outlook, rather this process benefits or maximizes the wealth of the whole society. As many inquiries is done on whether private firms perform better to anything state-owned enterprises (SOEs) and whether privatization enhances firm performance (Kocenda \& Svejnar, 2002). As this study contributes to the literature by describing that why privatization is more preferred and why it performed better then the state owned firms. And basically the purpose for which this research has been conducted is to identify the factors that can lead towards privatization.

\subsection{Hypotheses}

In keeping view the question of determinants of Privatization our hypothesis are:

$H_{1}$ : There is a significant relationship of GDP growth with privatization.

$\mathrm{H}_{2}$ : There is a significant relationship of imports with the privatization.

$\mathrm{H}_{3}$ : There is a significant relationship of exports with the privatization.

$\mathrm{H}_{4}$ : There is a significant relationship of external debt that leads towards privatization.

\section{Research Methodology}

This study is going to investigate the determinants of privatization by using ordinary least square (OLS) multiple regressive model. The privatization commission of Pakistan has recorded the proceeds from individual privatized transactions, including full and partial transaction that has been started in Pakistan since 1991. In this paper we are interested to see privatized transaction that generate income for the government and how they perform in the existing state owned assets, so the data that has been used in this research is based on secondary data that has been collected from privatization commission of Pakistan (PCP), state bank of Pakistan and some other sources. As the privatization process was started in Pakistan since 1991, so the time period that has been considered and taken as from 1991-2014.

\subsection{Variables of the Study}

The dependent variable is "privatization revenue as a percentage of GDP" is taken from the privatization commission of Pakistan (PCP). It has been previously used by Breen, Doyle, (2013), Brune , Garrett and Kognut, (2004) and help us know that how much privatization has been done in different areas and how much it proved to be useful. In this variable we see that how much privatization has been done in Pakistan and what are the percentages of this amount in GDP. The other explanatory variables that capture the long and short term economic condition of a country. Firstly, we include Gross domestic product (GDP) that is the financial estimation of all the completed products and services that is produced inside the boundary of a country in a particular time period. In spite of this GDP is commonly calculated on a yearly premise, it can be computed on a quarterly basis too. It includes all public and private consumptions, government costs, in simple worlds GDP is the measurement of whole economic activity. 
Secondly, we take "imports and exports as a percentage of GDP" that can capture the degree of a nation's financial interdependence with the rest of the world. Imports is simply good or services that is brought into one nation from another, The higher the estimation of imports entering a nation, compared with the estimation of exports, the more harmful that nation's exchange gets to be. And In worldwide exchange, "exports" refers to offering products and services created within a boundary of nation for different markets. Higher the ratio of exports shows the more stable that country exchange gets to be and both these variables is taken from state bank of Pakistan database. And finally, we include external debt, we expect that if external debt level is high then in order to raise revenue to pay the debt amount and to reduce the fiscal deficit of the country, it might result in privatization that can reduce their debt level and also attract investment opportunities. All of these variables are taken from state bank of Pakistan database and some various other sources.

\subsection{Model Specification}

Model that we use in this research paper is ordinary least square (OLS) multiple regression model. The multiple regression model and its estimation using ordinary least squire (OLS) is probably and is most widely used model that can help in estimating the relationship between the dependent variable and a set of independent variables. As this model determine the linear relation between the dependent variable $(\mathrm{y})$ and with the set of explanatory variables $\mathrm{i}$-e $\mathrm{X}_{1}, \mathrm{X}_{2}, \mathrm{X}_{3}, \mathrm{X}_{4} \ldots \ldots \ldots \mathrm{X}_{\mathrm{N}}$. Although the model OLS multiple regression model is appropriate for this research. The basic form of this model is as follows:

$$
\mathrm{Y}=\mathrm{Xi} \beta+\mathrm{Ui}
$$

As this is the basic form of this equation that we discuss about the model in this paper in which " $y$ " represent the dependent variable and "Xi" represent the number of explanatory variables (independent variable) and "Ui" is the error term. Now the equation that is used in this research paper and can help in understanding the relationship between the variables, so the form of equation will be as follows:

In this multiple regression model

$$
Y=\alpha+\beta_{1} X_{1}+\beta_{2} X_{2}+\beta_{3} X_{3}+\beta_{4} X_{4}+\varepsilon
$$

"Y" represents the dependent variable i-e "privatization revenue as a percentage of GDP”,

" $\alpha$ " represents the constant value,

" $\beta_{1} X_{1}$ "shows the value of GDP,

" $\beta_{2} X_{2}$ " represents the value of external debt,

" $\beta_{3} X_{3}$ "shows that how much exports bring change in dependent variable and

" $\beta_{4} X_{4}$ "represent the value of exports and

" $\varepsilon$ " represent error term.

So by putting the values in excel sheet and then run it through "gretl model" by using ordinary least square multiple regression model, it gives the following results: 


\section{Discussion and Analysis}

Model 1: OLS, using observations 1991-2014 ( $\mathrm{T}=23)$

Dependent variable: Privatized transactions year wise

Table no 4.1

\begin{tabular}{|lcllll|}
\hline & Coefficient & Std. Error & t-ratio & p-value & \\
\hline $\begin{array}{l}\text { Const } \\
\text { GDP current }\end{array}$ & US -90637 & 178188 & 1.6255 & 0.1214 & $* *$ \\
dollars & & 346.704 & -2.6152 & 0.0175 & $* * 2$ \\
$\begin{array}{l}\text { External debt } \\
\text { Exports percent of } 9778.2\end{array}$ & -7329.02 & 1809.53 & -4.0502 & 0.0008 & $* * *$ \\
$\begin{array}{l}\text { GDP } \\
\text { Imports percent of }-1215.43\end{array}$ & 3547.43 & 1.1440 & 0.2676 & \\
GDP & 3432.72 & -0.3541 & 0.7274 & \\
\hline
\end{tabular}

Table No.4.1 \& 4.2 presents our findings for 1991-2014, in this model it shows "P-value" and T-ratio" that represents the significant and insignificant level of result. The hypothesis for T-ratio shows that if $\mathrm{T}_{\text {cal }}>\mathrm{T}_{\text {tab }}$ then reject " $\mathrm{H}_{\mathrm{o}}$ " and accept " $\mathrm{H}_{1}$ " i-e if $\mathrm{T}_{\text {cal }}>$ 2 or -2 then reject $\mathrm{H}_{\mathrm{o}}$ and accept $\mathrm{H}_{1}$ while $\mathrm{P}$-value represent that if $\mathrm{P}$-value $<.05$ then reject $\mathrm{H}_{0}$ and accept $\mathrm{H}_{1}$, in both $\mathrm{P}$-value and T-ratio if " $\mathrm{H}_{1}$ " is accepted then it shows significant result and if " $\mathrm{H}_{0}$ " is accepted then it represent insignificant result. $\mathrm{R}$-square shows that how much the model is explaining variations independent variable or how much change independent variables brought in dependent variable and "F-STATISTICS" represent that whether the model is fit or not. I-e, $\mathrm{H}_{\mathrm{o}}$ - The fit model is not good.

$\mathrm{H}_{1}-$ The model fit is good.

In the above table4.1, in first row the value of " $\alpha$ " is "289637" and t-ratio is " 1.6255 " that is less then ' 2 ', so $\mathrm{H}_{\mathrm{o}}$ will be accepted and $\mathrm{H}_{1}$ will be rejected and p-value is " 0.1214 " that is greater than 0.05 , so here $\mathrm{H}_{\mathrm{o}}$ is also accepted and $\mathrm{H}_{1}$ will be rejected. In both the cases $\mathrm{H}_{\mathrm{o}}$ is accepted so the result is insignificant and also this first row shows that if all other explanatory variables are ' 0 ' then in dependent variable this much change will occur.
GDP: -906.699 '
T-ratio: -2.6152
P-value: 0.0175

In table 4.1, the second row represent the value of GDP that is ' -906.7 ', t-ratio is ' -2.6152 ' which is greater than ' -2 ', here $\mathrm{H}_{1}$ is accepted and $\mathrm{H}_{0}$ is rejected and $\mathrm{p}$-value is ' 0.0175 ' that is less than ' 0.05 ' that show that here $\mathrm{H}_{1}$ is also accepted and $\mathrm{H}_{0}$ will be rejected. Both the results show that $\mathrm{H} 1$ is accepted and when we reject $\mathrm{H} 0$ then it mean that the results are significant and it shows that beta value is not equal to zero, it has some value and that value is (-906.7), it explain that if a countries GDP is going towards downward then in that country there will be more privatization and that government try to stabilize their GDP and trying to increase it by adopting the process of privatization. As this result shows that when you have less money in a country then government try to attract more money and it can be done through privatization. 
GDP: $\quad-7329.02$

T-ratio: -4.0502

P-value: 0.0008

The third row in table 4.1 shows the impact of external debt on privatization, the value of external debt is ' -7329.02 ' and its t-ratio ' -4.0502 ' that shows that it is greater than its standard value so here $\mathrm{H} 1$ will be accepted and $\mathrm{H} 0$ will be rejected and while by looking at the p-value ' 0.0008 ' that identify that it is less than ' 0.05 ' so here also H1 is accepted and $\mathrm{H} 0$ will be rejected, that can specify that the result is significant and it shows that beta $(\alpha)$ value is not equal to zero, it has the value i-e (-7329.02), then it mean that when there is more external debt then it mean that there is less privatization as the result calculated. When there is less money with the government then they have two possibilities that either to take loan or either to privatize more frequently to pay the debt amount and to recover or to stabilize their economy, so by privatizing more government sectors that can reduce their debt ratio and fulfill their requirements. So it shows that when they take loan then they can't implement more privatization and also people's pressurize the governments that not to implement or adopt more privatization because people's feels secure when they are in hands of the state but on the other hand when we see the overall global trend of privatization and the results of the privatization then it shows improvement in overall conditions of the country, so due to the pressure by public they prefer to take loan to reduce their external debt rather than giving preference to privatization.

GDP: $\quad 9778.2$

T-ratio: 1.1440

P-value: 0.2676

By looking at the third row in the table 4.1 that represents the relationship between the exports and privatization. The value of exports is '9778.2' and the t-ratio is ' 1.1440 ' that is less than ' 2 ' which mean that here $\mathrm{H} 0$ is accepted and $\mathrm{H} 1$ is rejected and the p-value shows that ' 0.2676 ', that is greater than ' 0.05 ' so here $\mathrm{H} 0$ is accepted and $\mathrm{H} 1$ is rejected. Again in both the cases H0 is accepted, which mean that the result is insignificant, here it shows positive relationship between exports and privatization. As this result suggested that when there is more privatization in a country then there will be more exports. As in privatization, there is more production and produced quality products that can lead them to exports there products. Here in this result beta is equal to zero because both the t-ratio and p-value accept $\mathrm{H} 0$.

GDP : -1215.43

T-ratio: -0.3541

P-value: 0.7274

In table 4.1 the fourth row and their result show negative relationship between imports and privatization, as it shows that when imports increases then there will be less or no privatization and the value of imports is ' -1215.43 '. The value of t-ratio i-e '0.3541 ' represent that it is less than ' -2 ' so $\mathrm{H} 0$ will be accepted and in p-value i-e ' 0.7274 ' it shows that it is more than the standard value ' 0.5 ' so here also $\mathrm{H} 0$ is accepted. In both the cases they reject $\mathrm{H}_{1}$ and accept $\mathrm{H}_{0}$, so the result is insignificant, here it shows 
that beta ' $\alpha$ ' value is equal to zero. As when the country imports increases it shows that people demanding for new product and services, the internal things or internally what is being producing is not fulfilling the citizens demand, therefore they are demanding form outside the country i-e new innovative and quality products, that directly increase the ratio of imports and by thinking it from another side that if privatization increases that there will be less imports. If government adopts the process of privatization more frequently then as we study the global era of privatization it shows overall improvement and that country focus on exporting more things rather than importing products or other things. In privatization, it focuses on customer demand and fulfilling it, so then there will be no need of importing such things that is being fulfilled within the boundary of the country. When privatization increases then it increases the money supply in a country and that existing industry will give you quality product with in the country.

Table no 4.2

\begin{tabular}{|lcll|}
\hline Mean dependent var & 20699.30 & S.D. dependent var & 45916.18 \\
Sum squared resid & $2.38 \mathrm{e}+10$ & S.E. of regression & 36340.13 \\
R-squared & 0.487503 & Adjusted R-squared & 0.373615 \\
F(4, 18) & 4.280540 & P-value(F) & 0.013140 \\
Log-likelihood & -271.3323 & Akaike criterion & 552.6645 \\
Schwarz criterion & 558.3420 & Hannan-Quinn & 554.0924 \\
Rho & -0.382789 & Durbin-Watson & 2.723994 \\
\hline
\end{tabular}

R-squared: 0.487503

P-value (F): 0.013140

In table 4.2 the R-squared value shows that how much independent variable bring change in dependent variable, so by looking at the value of R-square i-e ' 0.487503 ' it represent that about $48.75 \%$ change is bring by these four variable and the rest almost $52 \%$ is remained un-explained and the P-value of F-statistics shows that the model that is being used is good or not, so by looking at the p-value (F) i-e ' 0.013140 ' shows that it is less than the standard value, so here $\mathrm{H} 0$ is rejected and $\mathrm{H} 1$ is accepted, so accordingly $\mathrm{H} 1$ shows that;"The model fit is good". 
Table 3: Descriptive Statistics

\begin{tabular}{|c|c|c|c|c|c|c|c|}
\hline & $\begin{array}{c}\text { Economic } \\
\text { growth }\end{array}$ & GDP & $\begin{array}{l}\text { GDPper } \\
\text { capita }\end{array}$ & $\begin{array}{c}\text { External } \\
\text { debt }\end{array}$ & Exports & Imports & $\begin{array}{c}\text { Privatized } \\
\text { transactions } \\
\text { year wise }\end{array}$ \\
\hline$\frac{\text { Mean }}{\text { Standard }}$ & 4.078 & 114.22 & 3798.33 & 38.48 & 14.89 & 18.93 & 22670.416 \\
\hline$\frac{\overline{\text { Deviation }}}{\underline{\text { Sample }}}$ & 1.92 & 66.71 & 481.02 & 13.09 & 1.71 & 2.36 & 45933.400 \\
\hline Variance & 3.69 & 4450.48 & 231377.33 & 171.30 & 2.91 & 5.60 & 2109877287 \\
\hline Range & 6.7 & 201.43 & 1497.67 & 54.58 & 5.01 & 8.58 & 212141 \\
\hline$\underline{\text { Minimum }}$ & 1.01 & 45.45 & 3123.83 & 0 & 12.35 & 14.63 & 0 \\
\hline Maximum & 7.71 & 246.88 & 4621.5 & 54.58 & 17.36 & 23.21 & 212141 \\
\hline Count & 24 & 24 & 24 & 24 & 24 & 24 & 24 \\
\hline
\end{tabular}

In table 4.3, it shows descriptive statistics of all variables and expressed their findings Quantitatively. Mean shows the average level, while standard deviation shows the volatility between specified periods. As maximum shows the highest value while minimum shows the lowest value between the quantified period and Range is the difference between the Maximum and Minimum value and the last row of Count represent the number of Observations. Economic growth, External debt, Exports and Imports signify their values in the form of percentages. As explained above mean show the average, so the average of economic growth is 4.078 , external debt 38.483, exports 14.894 and imports is 18.934 for the period of 1991-2014. Their Standard deviation shows the variations in economic growth about 1.919, external debt 13.0883, exports 1.706 and in imports i-e 2.366 percent. And Range shows the alteration between the Maximum and Minimum value, so by looking at the table, range represent that there is a change in economic growth by 6.7 percent, in external debt by 54.58 percent, exports 5.01 and in imports there is 8.58 percent changed. The figure of GDP, GDP per capita and Privatized transaction year wise is shown in million for the period of 1991-2014. It is showing that the average value of GDP is 114.215 million, GDP per capita 3798.33 million, and the mean value of privatized transaction is 22670.417 million. The standard deviation shows the variations in GDP is up to 66.712 million, in GDP per capita 481.017 million and in privatized transaction year wise is 45933.401 million. Range represent the change in GDP which is 201.43, in GDP per capita 1497.67 and the difference between the highest and lowest point of privatized transaction is 212141 million. In table 3 , count shows in last row a total number of observations are 24 for the period of 1991-2014.

\section{Conclusion}

As the recent trend of privatization specify that SOEs are not performing well that can trigger the process of privatization and since form 1990's it has turned out to be a most crucial for both the developing countries as well as for the developed countries. However, there have been very limited studies that can identify the determinants that can initiate the process of privatization and having limited data and methodological 
restriction. As we put together on this paper and utilized widespread dataset on productive sector form the state bank of Pakistan and privatization commission of Pakistan as a reliable source. The model that we use in this research is Ordinary least squire (OLS) multiple regression model that can identify the relationship between dependent variable and explanatory variables and can identify the main determinants of privatization in Pakistan between the years of 1991 to 2014. Our results identify a number of essential factors. Firstly, the internal and external pressure plays an essential role at different stages of the policy making process. The initial decision to adopt privatization in mostly developing countries is largely depend and shaped by exogenous factors.

The desire to compete with the privatizing states, the influential factors from the IMF and all other factors that can encourage the developing countries to implement privatization but our results indicates that when the SOEs are not performing well that can reduce the GDP of a country that can trigger the privatization process as by looking the overall trend of privatization and the improvement in overall economic condition but on the other side if the decrease in the GDP can lead that state to take money from international financial institutions then there is less chances of privatization as when a country fulfill their monetary requirement from financial institutions then it can increase their debt level that alters lower down the chances of privatization. As there has been no doubt that the privatization process has been initiated from outside the partisan system while once the decision has made, to adopt the level and extent of privatization is the primarily function of internal partisan and economic concern. There is not only one and unique explanation for privatization all has some relevance but rather it has different benefits while applied across in different times and stages (Meseguer 2004; Doyle 2010). The integration in global trade of a country intends them to privatize less while those who are not involved in global trading are more persuaded to privatize. As our results indicates that when privatization increases it can reduce the ratio of imports and it increases the level of exports.

\section{References}

Bennett, J., Saul, E. \& Giovanni, U. (2007). Methods of Privatization and Economic Growth in Transition Economies. Economics of Transition, vol. 15(4), pp. 661683.

Bernardo, B. \& Paolo P. (2003). The Political Economy of Privatization, July 23, 2010, Social Science Research Network, www.ssrn.com.

Biais, B. \& Perotti, E. (1999). Machiavellian Privatization, American Economic Review.

Bortolotti, B., Fantini, M. \& Siniscalco, D. (2001). Privatisation: politics, institutions, and financial markets. Emerging Markets Review (2).

Bortolotti, B. \& Milella, V. (2006). Privatization in Western Europe Stylized Facts, Outcomes, and Open Issues, Nota di Lavoro, Fondazione Eni Enrico Mattei, Vol. 124.

Bortolotti, B. \& Siniscalco, D. \& Fantini, M. (2000). Privatisation and Institutions: A Cross Country Analysis, CESifo Working Paper, No. 375.

Boutchkova, M., \& Megginson, W. (2000). The Impact of Privatization on Capital 
Market Development and Individual Share Ownership, Unpubl. Working Paper, $O E C D$.

Doyle, D. (2010). Politics and privatization: Exogenous pressures, domestic incentives and state divestiture in Latin America. Journal of Public Policy, 30(3), pp. 291320.

Doyle, D. (2012). Pressures to privatize? The IMF, globalization, and partisanship in Latin America. Political Research Quarterly, 65(3), pp. 572-585.

Galal, A., Jones, L., Tandon, P., \& Vogelsang, I. (1994) Welfare Consequences of Selling Public Enterprises, New York: Oxford University Press.

Gupta, N. (2001). Partial Privatization and Firm Performance: Evidence from India, Assessed January 23, 2009, Social Science Research Network, www.ssrn.com.

Hassan, M. K. (1994). The Privatization of Commercial Banks in Bangladesh. paper presented at the 1995 Financial Management Association Annual Meeting, New York, October 19-21, 1995.

Juliet, D., Willaim, M., \& Robert, N. (2001). Determinants of performance improvement in privatized firms: the role of restructuring and corporate governance. SSRNid243186.

Khan, A. (2010). Is privatization in pakistan purposeful? Assessed July 23, 2010, Pakistan Institute of Development Economics, www.pide.org.pk.

Leeds, R. (1991). Privatization Through Public Offerings: Lessons from Two Jamaican Cases. in Ravi Ramamurti and Raymond Vernon, eds: Privatization and Control of State-Owned Enterprises (The World Bank, Washington, D.C.), 86-125.

McKenzie, D. \& Dilip, M. (2003). Distributive Impact of Privatization in Latin America: An Overview of Evidence from Four Countries. Economia, vol. 3(2), pp. 161218.

Megginson, W. L., Robert, C. N. \& Matthias, V. R. (1994). The financial and operating performance of newly privatized firms: An international empirical analysis. Journal of Finance 49, 403-452.

Michael, B. \& David, D. (2013). The Determinants of Privatization: a Comparative Analysis of Developing Countries. Journal of Comparative Policy Analysis: Research and Practice, 15:1, 1-20, DOI: 10.1080/13876988.2013.741439.

Perotti, E. C. \& Serhat, E. G. (1993). The Structure of Privatization Plans. Financial Management, Vol. 22( l), 84-98.

Pop-Eleches, G. (2009). From economic crisis to reform: IMF programs in Latin America and Eastern Europe (Princeton, NJ: Princeton University Press).

Reimut, Z., H. O. \& Frieder, W. (2008). Partisan Politics, Globalization, and the Determinants of Privatization Proceeds in Advanced Democracies (1990-2000). An International Journal of Policy, Administration, and Institutions, Vol. 21(1).

Schumacher, U. \& Gladstone, H. (1991). Privatization in Developing Economies: The Case of Jamaica. in Attiat F. Ott and Keith Hartley, eds: Privatization and Economic Efficiency, (Edward Elgar), 87-107.

Shahzad, U. (2005). Privatization in Bangladesh: The Emergence of 'Family Capitalism' Development and Change, 36(1), Institute of Social Studies. 
Shaukat, A. (2011). Privatization for Economics prosperity: a case study of Pakistan. COMSATS institute of information technology, Attock, Pakistan.

Treisman, D. (2003). Cardoso, Menem, and Machiavelli: Political tactics and privatization in Latin America. Studies in Comparative International Development, 38(3), pp. 93-109.

Vickers, J., \& Yarrow, G. (1988). Privatization: An Economic Analysis, Cambridge (Mass.): MIT Press.

Zinnes, C., Yair, E. \& Jeffrey, S. (2001). The Gains from Privatization in Transition Economies: Is 'Change of Ownership' Enough? IMF Staff Papers, Special Issue, 48, pp. $146-170$. 